Hydrol. Earth Syst. Sci., 17, 1503-1516, 2013

www.hydrol-earth-syst-sci.net/17/1503/2013/

doi:10.5194/hess-17-1503-2013

(C) Author(s) 2013. CC Attribution 3.0 License.

\title{
Trends in timing and magnitude of flow in the Upper Indus Basin
}

\author{
M. Sharif ${ }^{1}$, D. R. Archer ${ }^{2}$, H. J. Fowler ${ }^{3}$, and N. Forsythe ${ }^{3}$ \\ ${ }^{1}$ Department of Civil Engineering, Jamia Millia Islamia University, Jamia Nagar, New Delhi 110025, India \\ ${ }^{2}$ JBA Consulting Engineers and Scientists, South Barn, Broughton Hall, Skipton, North Yorks. BD23 3AE, UK \\ ${ }^{3}$ Water Resource Systems Research Laboratory, School of Civil Engineering and Geosciences, Newcastle University, \\ Tyne And Wear, UK
}

Correspondence to: D. R. Archer (david.archer@jbaconsulting.com)

Received: 10 August 2012 - Published in Hydrol. Earth Syst. Sci. Discuss.: 3 September 2012

Revised: 20 November 2012 - Accepted: 18 March 2013 - Published: 19 April 2013

\begin{abstract}
River flow is a reflection of the input of moisture and its transformation in storage and transmission over the catchment. In the Upper Indus Basin (UIB), since highaltitude climate measurement and observations of glacier mass balance are weak or absent, analysis of trends in magnitude and timing in river flow provides a window on trends and fluctuations in climate and glacier outflow. Trend analysis is carried out using a Mann-Kendall nonparametric trend test on records extending from 1960 to 1998. High-level glacial catchments show a falling trend in runoff magnitude and a declining proportion of glacial contribution to the main stem of the Indus. Elsewhere annual flow has predominantly increased with several stations exhibiting statistically significant positive trends. Analysis of timing using spring onset date (SOT) and centre of volume date $(\mathrm{CoV})$ indicated no clear trends - in direct contrast to what has been observed in western North America. There is, however, a consistent relationship between $\mathrm{CoV}$ and annual runoff volume. A consistently positive correlation was also found between SOT and $\mathrm{CoV}$ for all the stations, implying that initial snowpack conditions before the onset of runoff influence timing throughout the season. The results of the analysis presented here indicate that the magnitude and timing of streamflow hydrograph is influenced both by the initial snowpack and by seasonally varied trends in temperature. The study contributes to the understanding of the links between climate trends and variability and river runoff and glacier mass balance and runoff. The Upper Indus Basin is predominantly influenced by winter precipitation; similar trend analysis applied to summermonsoon-dominated catchments of the central Himalaya is recommended.
\end{abstract}

\section{Introduction}

\subsection{Context and objective}

The now-refuted statements (WWF, 2005; IPCC, 2007) concerning the predicted rapid retreat and disappearance of $\mathrm{Hi}-$ malayan glaciers and consequent drastic reduction in downstream river flows has spurred vigorous debate on changes in glacier mass balance (Berthier et al., 2007; Eriksson et al., 2009) and river flow, and the nature and role of climate trends and variability (Immerzeel et al., 2008; Bookhagen and Burbank, 2010). Nevertheless, understanding of links between climate, glacier mass balance and river flow remains weak (Stahl et al., 2006) primarily because ground-based high-altitude climate measurement is limited both for direct analysis and for validation of satellite remotely sensed data.

Concerns about the potential impacts of climate change on flow in the Indus (Rees and Collins, 2006), given temperature changes in line with global climate change projections (Cruz et al., 2007), have given rise to expectations of dramatic decreases in river flow volume (Briscoe and Qamar, 2007; Immerzeel et al., 2008). However, there is evidence that historic climatic trends in the Upper Indus Basin (UIB) have not fallen in line with global trends with respect to seasonal trends in temperature (Fowler and Archer, 2006) or precipitation (Archer and Fowler, 2004). Sheikh et al. (2009) have provided an assessment for the whole of Pakistan of changes in climatic variables, again showing significant departures from the global pattern. However, limited attention has been paid to historic changes in river flow, which can provide a reflection of the climatic input of moisture and its transformation in storage and transmission over the river 
catchment. In the case of the Himalaya-Karakoram-Hindu Kush (HKH), the principal transforming storages are in seasonal snow and glacier ice.

Flow from the River Indus provides the basis for irrigated agriculture, which is the mainstay of the economy of Pakistan. Any change in the flow regime, either in magnitude or in timing, could have a serious impact on the livelihoods not only of those engaged in the agricultural sector but for the economy as a whole (Archer et al., 2010). Since most of the runoff is derived from the melting of seasonally accumulated snow and ice from glaciers, flow magnitude and timing in the Indus are vulnerable to changes in both temperature and precipitation (Archer and Fowler, 2004; Fowler and Archer, 2006). Changes in timing of runoff, with or without changes in magnitude, could also have serious implications for water management and especially for the operating rules for large reservoirs at Tarbela (Indus) and Mangla (Jhelum) which control the flow to the Indus Basin Irrigation System.

A previous study by Khattak et al. (2011) assessed trends in monthly mean flow at eight stations in the UIB and found predominantly increasing trends in winter and decreasing trends in summer. This paper extends the number of stations to nineteen for assessment of trends with the aim of identifying trends and other patterns of change in both magnitude and timing of runoff response for flow-gauging stations in UIB (Fig. 1). Section 1.2 details some insights from global runoff trends which are relevant for the study of trends in runoff in the UIB. Section 2 then gives some detail on the particular high mountain environment of the UIB. Sections 3 and 4 describe the data sources and methods used in this study. Section 5 gives the results of the study in terms of the trends in mean flows but also patterns of change in the magnitude and timing of runoff response in the UIB. Section 6 discusses these results in the context of those occurring in other mountainous regions with glacier or snowmelt input to runoff, notably in western North America, and attempts to relate seasonal and annual patterns of change in runoff to the driving changes in energy input (characterized by temperature) and precipitation. Section 7 gives some concluding remarks on the study.

\subsection{Insights from global runoff trends}

Changes to the timing of river flows in other regions with significant snowmelt contribution such as the western United States have been extensively studied and are considered here as a basis for establishing methods and measures and for insights on the impact of climate change on runoff. Initially research in the western United States concentrated on trends in the percentage of seasonal to annual runoff. Roos (1987) found a decreasing trend in the percentage of annual runoff from April to July in the Sacramento River system even when annual streamflow and precipitation did not have a downward trend. Aguado et al. (1992) extended the study with data from 1948 to 1986 to show that over the Sierra Nevada not only had spring flow decreased but autumn and winter flow had increased. Both higher winter precipitation and higher spring temperature were identified as potential causes of the change in streamflow timing.

Subsequent analysis (Cayan et al., 2001), using daily data, found that the timing of the first pulse of spring streamflow in the western United States occurred 5 to 10 days earlier in the last half of a $50 \mathrm{yr}$ record starting in 1950 than they did in the first half. Increased winter and spring temperatures were identified as exerting the greatest influence on changes in spring onset. Burn (1994) and Westmacott and Burn (1997) also found a strong shift toward the early occurrence of the spring runoff events over west central Canada.

Measures of the timing of the centre of volume $(\mathrm{CoV})$ of the snowmelt hydrograph also showed changes in western North America. Regonda et al. (2005) found that over the second half of the twentieth century shifts in timing appeared to vary with elevation, being typically 10 to 20 days earlier in basins less than $2500 \mathrm{~m}$ elevation, but little changed in basins greater than $2500 \mathrm{~m}$. In lower basins, where winter temperatures are close to melting point, trends were influenced by a change in the proportion of precipitation that fell as rain rather than snow. Barnett et al. (2008) and Hidalgo et al. (2009) found that the observed trends toward earlier $\mathrm{CoV}$ of snowmelt-driven hydrographs in the western United States since 1950 were detectably different from natural variability. Déry et al. (2009) drew attention to the fact that $\mathrm{CoV}$ may be influenced by runoff magnitude as well as temperature changes, illustrated by significant relationships between runoff volume and CoV. They also argue that changes in comparative contributions from melt of seasonal snow, from glaciers and from direct runoff from rainfall, can affect timing in rivers in western Canada.

Dettinger and Diaz (2000) provided a global context for such CoV timing trends. They noted that, while some of the largest trends toward earlier spring melt occurred in western North America, similar trends occurred in rivers worldwide during the period from 1945 to 1993. Significant trends are found in rivers throughout eastern Europe and western Russia, across Canada, and in parts of the Southern Hemisphere. Catchments where cool-season temperatures are near to melting point showed the largest changes in streamflow timing.

Whilst observations of changes in streamflow timing in the western United States and their attribution can provide a basis for understanding and analysis of changes in the Upper Indus Basin, differences in climate and topography are expected to influence streamflow timing in a quite different manner. In addition it is anticipated that the comparative contributions of melt of glaciers and of seasonal snow, and concurrent contributions from precipitation falling as rain either from westerly disturbances in winter and spring or from summer monsoon rainfall, will result in within-region differences both in timing and timing trends. Significant features of climate and topography are therefore outlined below. 


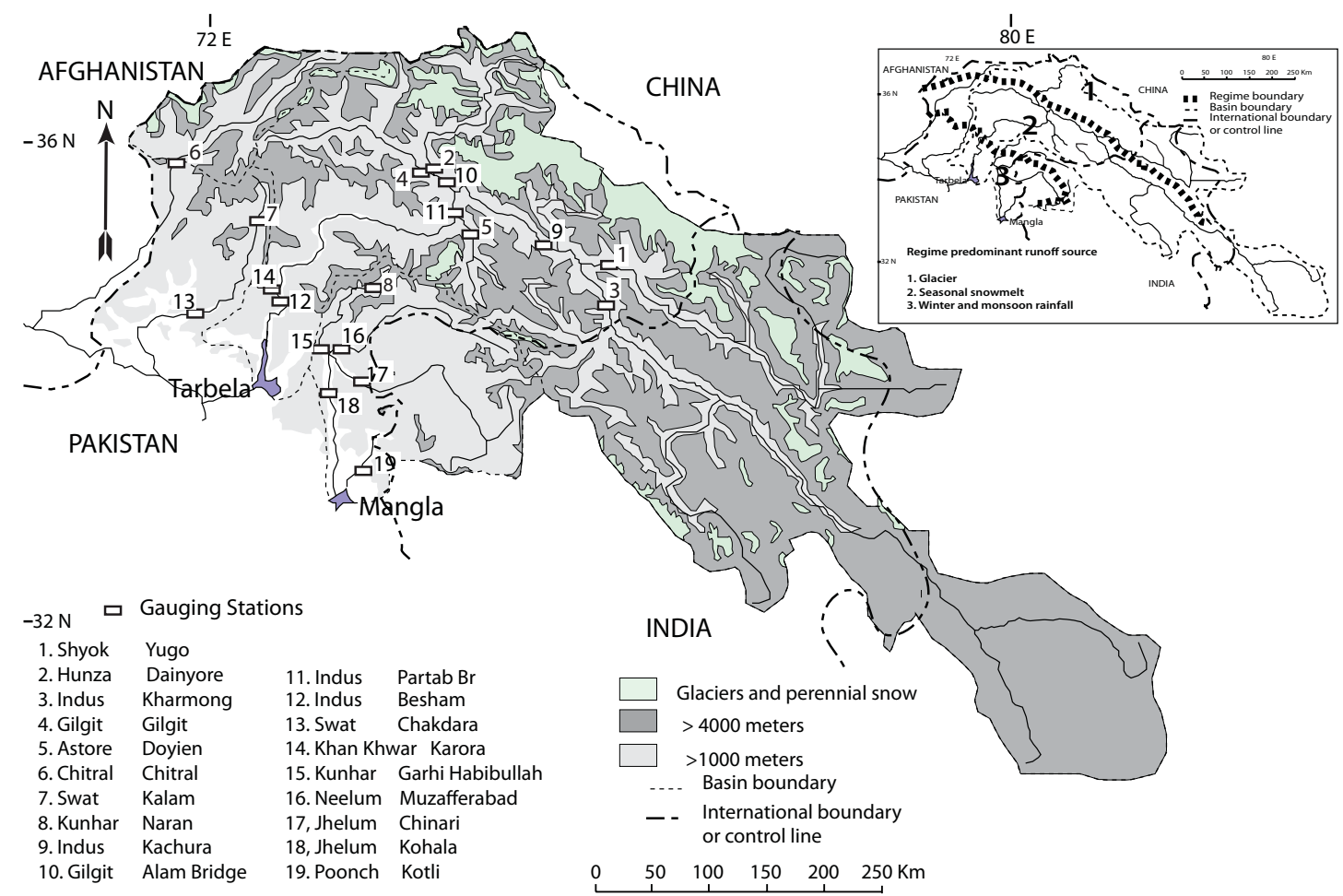

Fig. 1. The Upper Indus Basin showing gauging stations (listed in Table 1) used in this analysis. Inset shows approximate boundaries of regimes by predominant runoff source

\section{The environment of the Upper Indus Basin}

The UIB stretches from the Hindu Kush Range on the borders of Afghanistan through the Karakoram Range to the western margins of the Tibetan Plateau (Fig. 1). On its southern fringe the Himalaya extends westward to the Nanga Parbat massif and acts as a barrier to the northward incursion of the summer monsoon. The basin area to the water management reservoir on the Indus at Tarbela is $168000 \mathrm{~km}^{2}$ and to the Jhelum at Mangla is $33342 \mathrm{~km}^{2}$. It has a much wider range of elevation than the basins of the western United States. This mountain region has many peaks exceeding $7000 \mathrm{~m}$ and contains the greatest area of perennial glacial ice outside the polar regions $\left(22000 \mathrm{~km}^{2}\right)$, with several thousand individual glaciers. The area of winter snow cover is an order of magnitude greater. The mean elevation of the Indus Basin to Tarbela is more than $4000 \mathrm{~m}$.

Climatic variables are strongly influenced by altitude. Northern valley floors are arid with annual precipitation typically in the range of 100 to $200 \mathrm{~mm}$, but precipitation increases with elevation to more than $600 \mathrm{~mm}$ at $4400 \mathrm{~m}$ (Cramer, 1993), and glaciological studies suggest accumulation rates of 1500 to $2000 \mathrm{~mm}$ at $5500 \mathrm{~m}$ (Wake, 1989). Since most of the precipitation north of the Himalaya occurs in winter and arises from westerly waves (Archer and Fowler, 2004), and mean monthly temperatures from October to
March are below freezing above $3000 \mathrm{~m}$ (Archer, 2004), there is virtually no direct runoff from rainfall during these months. The monsoon makes brief and infrequent incursions between July and September, but the amount of precipitation which it brings diminishes rapidly from south-east to north-west. Extreme monsoon incursions are paradoxically accompanied by a decrease in river flow as precipitation as snow is accompanied by a sharp fall in temperature and reduced ablation (Archer, 2004). Hence runoff from tributaries in the Karakoram and Hindu Kush is primarily derived from glacier melt in the highest catchments such as the Hunza and Shyok, and from the melt of seasonal snow in middleelevation catchments such as Astore and parts of the upper Indus (Archer, 2003) and Jhelum (Archer and Fowler, 2008).

In southward-oriented valleys, climate stations have sharply increased annual precipitation totals mainly with the rapid growth in summer monsoon (July to September) precipitation. Lower tributaries on the southern slopes of the Himalayas experience significant direct runoff from summer monsoon precipitation and, to a lesser extent, from winter and spring rainfall.

The contrast in runoff regimes between catchments predominantly fed by glacier melt, snowmelt or monsoon rainfall is sharply illustrated by spatial variations in timing of the annual maximum of mean daily flow shown in Fig. 2. The two highest catchments, the Hunza at Dainyore (panel a) and 
Table 1. River-flow-gauging stations and characteristics of their catchments.

\begin{tabular}{|c|c|c|c|c|c|c|c|c|c|c|}
\hline $\begin{array}{l}\text { Stn. } \\
\text { No. }\end{array}$ & River & Station & $\begin{array}{l}\text { Period of } \\
\text { available } \\
\text { record }\end{array}$ & $\begin{array}{r}\text { Basin } \\
\text { area } \\
\mathrm{km}^{2}\end{array}$ & $\begin{array}{r}\text { Mean } \\
\text { elevation } \\
m\end{array}$ & $\begin{array}{r}\text { Area above } \\
5000 \mathrm{~m} \\
\%\end{array}$ & $\begin{array}{r}\text { Mean } \\
\text { flow } \\
\mathrm{m}^{3} \mathrm{~s}^{-1}\end{array}$ & $\begin{array}{r}\text { Annual } \\
\text { Runoff } \\
\mathrm{mm} \mathrm{yr}^{-1}\end{array}$ & $\begin{array}{l}\text { Median } \\
\text { SOT }\end{array}$ & $\begin{array}{l}\text { Median } \\
\mathrm{CoV}\end{array}$ \\
\hline & \multicolumn{10}{|c|}{ (a) Gauging stations with available daily records } \\
\hline & \multicolumn{10}{|c|}{ Catchments with predominantly glacial melt regime } \\
\hline 1 & Shyok & Yogo & $1973-1997$ & $33350^{*}$ & 4900 & 46.2 & 347.1 & 328.4 & 12 Jun & 1 Aug \\
\hline \multirow[t]{2}{*}{2} & Hunza & Dainyore & $1966-1997$ & 13925 & 4472 & 35.8 & 338.6 & 767.3 & 4 Jun & $29 \mathrm{Jul}$ \\
\hline & \multicolumn{10}{|c|}{ Catchments with predominantly seasonal snowmelt regime } \\
\hline 3 & Indus & Kharmong & 1982-1997 & 72500 & 4755 & 36.7 & 489.1 & 212.9 & 18 May & $15 \mathrm{Jul}$ \\
\hline 4 & Gilgit & Gilgit & 1960-1998 & 12800 & 3740 & 2.9 & 281.9 & 694.7 & 26 May & $19 \mathrm{Jul}$ \\
\hline 5 & Astore & Doyian & 1974-1997 & 3750 & 3921 & 2.8 & 136.8 & 1150.0 & 4 Jun & $19 \mathrm{Jul}$ \\
\hline 6 & Chitral & Chitral & 1964-1996 & 12425 & 3794 & 8.1 & 271.9 & 690.0 & 29 May & $25 \mathrm{Jul}$ \\
\hline 7 & Swat & Kalam & 1961-1997 & 2025 & 3300 & 0.3 & 89.6 & 1395.9 & 5 May & $8 \mathrm{Jul}$ \\
\hline \multirow[t]{2}{*}{8} & Kunhar & Naran & 1960-1998 & 1175 & 3700 & 0.0 & 48.1 & 1290.4 & 5 May & $1 \mathrm{Jul}$ \\
\hline & \multicolumn{10}{|c|}{ Main river catchments with mixed glacial and seasonal snowmelt regime } \\
\hline 9 & Indus & Kachura & 1970-1997 & $115289^{*}$ & 4789 & 40.2 & 1069.1 & 292.6 & 26 May & $25 \mathrm{Jul}$ \\
\hline 10 & Gilgit & Alam Br & 1966-1998 & 27525 & 4094 & 18.1 & 644.0 & 737.9 & 29 May & $24 \mathrm{Jul}$ \\
\hline 11 & Indus & Partab Br & 1962-1996 & $145618^{*}$ & 4656 & 36.2 & 1775.8 & 384.8 & 28 May & $25 \mathrm{Jul}$ \\
\hline \multirow[t]{2}{*}{12} & Indus & Besham & 1969-1997 & $166096^{*}$ & 4505 & 32.6 & 2412.2 & 458.3 & 22 May & $21 \mathrm{Jul}$ \\
\hline & \multicolumn{10}{|c|}{ Catchments with mixed seasonal snowmelt and spring or monsoon rainfall } \\
\hline 13 & Swat & Chakdara & $1961-1997$ & 5400 & 2499 & 0.14 & 178.9 & 1044.8 & $12 \mathrm{Apr}$ & 29 Jun \\
\hline 14 & Khan Khwar & Karora & $1975-1996$ & 625 & 1906 & 0.0 & 21.2 & 1071.6 & 8 Mar & 2 Jun \\
\hline 15 & Kunhar & Garhi Habibullah & 1960-1998 & 2400 & 3061 & 0.0 & 101.8 & 1337.4 & $19 \mathrm{Apr}$ & 27 Jun \\
\hline 16 & Neelum & Muzafferabad & 1963-1995 & 7392 & 3215 & & 357 & 1524.0 & $6 \mathrm{Apr}$ & 13 Jun \\
\hline & \multicolumn{10}{|c|}{ (b) Additional stations with available monthly records (mixed seasonal snowmelt and monsoon rainfall) } \\
\hline 17 & Jhelum & Chinari & 1970-1995 & 13775 & 2437 & & 330 & 756.0 & & \\
\hline 18 & Jhelum & Kohala & $1965-1995$ & 25000 & 2629 & & 828 & 1045.2 & & \\
\hline 19 & Poonch & Kotli & $1960-1995$ & 3176 & 1805 & & 134 & 1333 & & \\
\hline
\end{tabular}

* Basin areas have been amended from previous papers by the authors, in line with revised assessment by Alford (2011) showing that the Pagong Lake catchment is a closed basin and does not contribute to the Shyok and downstream basins.

the Shyok at Yugo (panel b), with large glacier melt contributions have annual peaks in late July and August. Gilgit River at Gilgit (panel c) and Astore at Doyien (panel d) with lower mean elevations (Table 1) and predominantly seasonal snowmelt runoff have annual peaks in June and July. The main stem of the Indus at Besham (panel e) incorporates the runoff from both glacial and seasonal snowmelt and, depending on the predominant contribution, the annual peak ranges from the end of June to the middle of August. The southward-flowing River Swat at Chakdara (panel f) has a much broader spread of peak flow dates ranging from April, resulting from early snowmelt runoff and concurrent spring rainfall, to monsoon-related peaks in July and August and even extending into September (1992) and October (1987).

Previous analysis (Archer, 2003; Archer and Fowler, 2008) shows highly significant seasonal correlation between climate variables and runoff in the UIB but differing between runoff regimes. Hence trends in climate variables are expected to influence trends in both magnitude and timing of runoff. Fowler and Archer (2006), in analysing station data for the UIB, found strong contrasts between the trend behaviour of winter and summer temperatures and between maximum and minimum temperatures. Winter and spring mean and maximum temperature show significant increases, while mean and minimum summer temperatures show consistent decline over the period 1961 to 1999 . Figure 3 shows trends of monthly mean temperature for three principal climate stations compared with an ERA-40 global meteorological reanalysis data set from the European Centre for Medium-range Weather Forecasting (ECMWF) (Forsythe et al., 2010). There is general agreement in the pattern of seasonal trends between the two data sets.

As a consequence, trends in magnitude and timing of river flow might be expected to differ between high-level catchments where glacier melt is predominantly in summer and middle- and lower-level catchments where melt of seasonal snow occurs in spring and early summer. An effect of declining summer temperature on reduced summer runoff volume in the high-level Hunza catchment has already been identified (Fowler and Archer, 2006).

Annual and seasonal trends in precipitation from 1961 to 1999 at 10 stations in the UIB were investigated in Archer and Fowler (2004). All ten winter (October to March) trends were positive with three significant at $p<0.05$; positive 

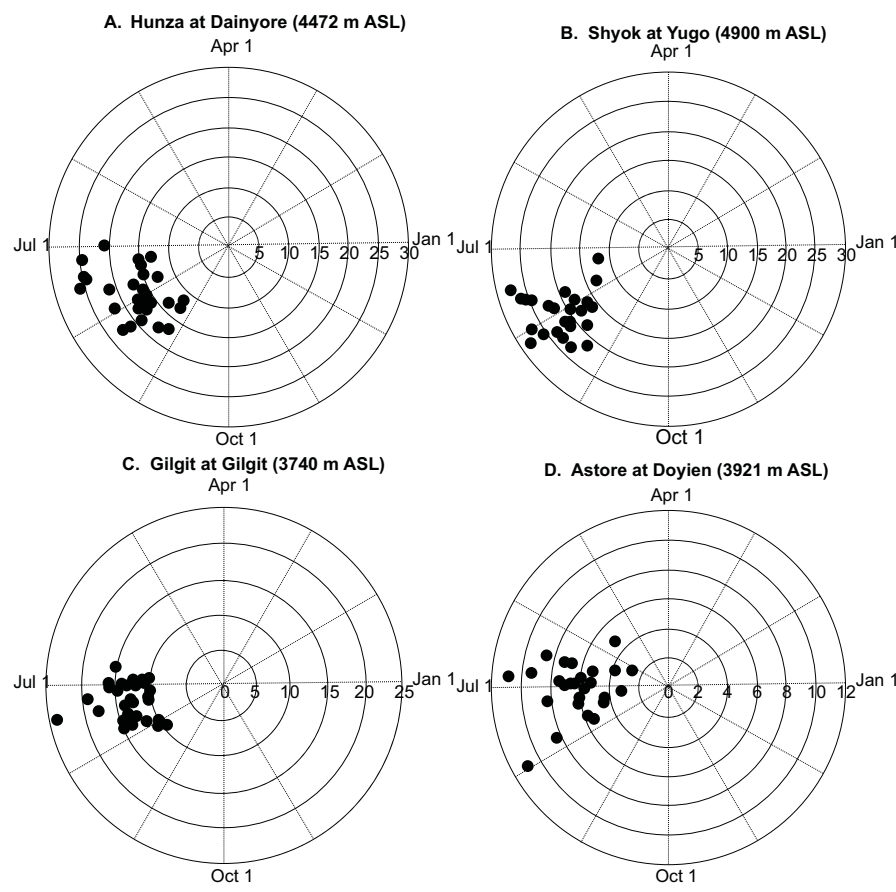

E. Indus at Besham (4505 $\mathrm{m}$ asl)

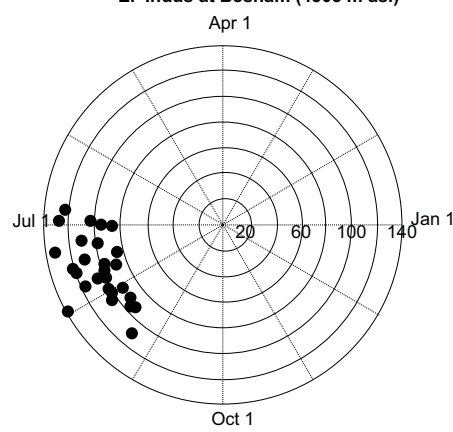

F. Swat at Chakdara $2499 \mathrm{~m}$ ASL)

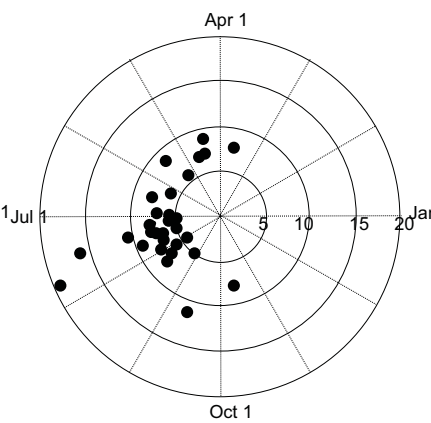

Fig. 2. Polar plots showing magnitude $\left(\mathrm{m}^{3} \mathrm{~s}^{-1} \times 100\right)$ and timing of annual peak daily flow at six representative stations. Mean catchment elevation is shown.

trends were identified at eight of ten stations in summer (April to September), but all were non-significant. Figure 4 shows trends in monthly precipitation for the same record period and climate stations as in Fig. 3, compared with the ERA-40 reanalysis data set. Winter upward trends are concentrated in the early winter, limited change occurs from February to April (except Gilgit), whilst increases are displayed in June and July. Since runoff on catchments predominantly fed by melt of winter snow show strong correlation between winter precipitation and subsequent summer runoff (Archer, 2003; Archer and Fowler, 2008), an upward trend in runoff magnitude in these catchments is also expected. Glacier-fed catchments are expected to be unaffected by preceding snowfall. These hypotheses are tested in this analysis.

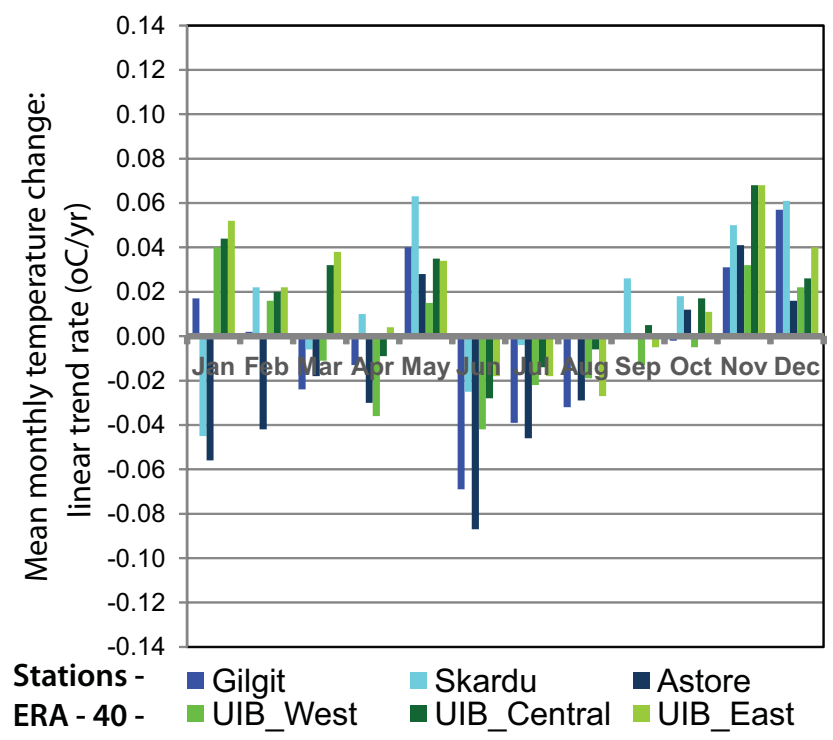

Fig. 3. Comparison of mean monthly temperature trends estimated using local observations and ERA-40 reanalysis data, common time period 1966-1995.

\section{Data}

The Pakistan Water and Power Development Authority (WAPDA) maintains a network of river-gauging stations covering the main stem of the Indus and its principal tributaries. For this study, daily flow records were available for 16 stations and a further 3 stations for monthly data only. The earliest record commences in 1960; 12 stations have records greater than $30 \mathrm{yr}$ duration and a further 6 in excess of $20 \mathrm{yr}$. The characteristics of these stations and catchments are shown in Table 1. Three caveats must be placed on conclusions drawn from the following analysis.

1. The analysis of trends and relationships depends on the accuracy of the raw data. Flow data are based on measurements of level, most frequently using manual observation, and the calibration of a stage discharge relationship derived by current metering from bridge or cableway. It is difficult to maintain discharge accuracy especially for high flows in mountain rivers, often with mobile bed and shifting control. Nevertheless, the general success in establishing relationships between independently measured climatic variables and flow (Archer, 2003) gives credibility to the measurements. In addition timing variables are less affected than magnitude variables.

2. The analysis is based on data up to 1998 . The absence of, and inability to acquire, more-recent flow data may limit the applicability of the results to future projections. During the recent decade the Indus has experienced exceptional droughts (2000-2003) (Ahmad et al., 2004) and exceptional monsoon rainfall (2010) (Houze et al., 


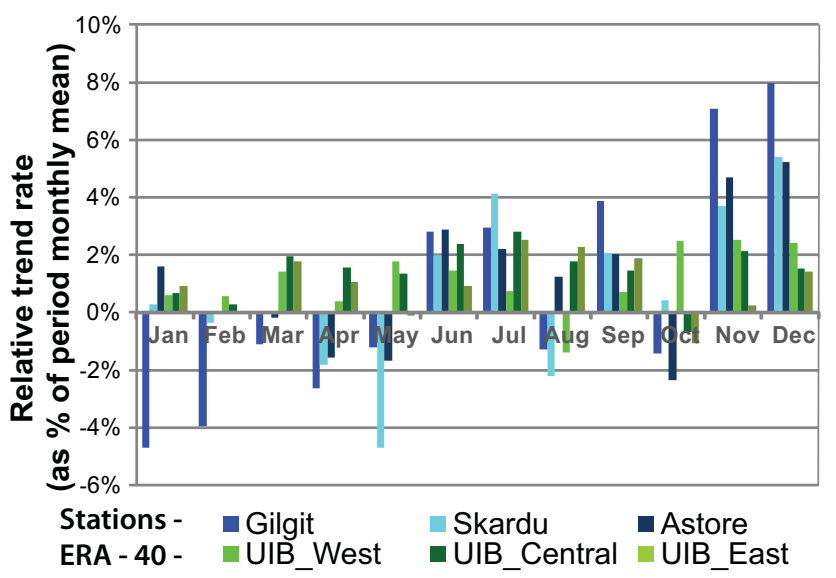

Fig. 4. Comparison of monthly precipitation trends using local observations and ERA-40 reanalysis data, 1966-1995.

2011), which affected streamflow and may thus influence trend assessments.

3. Streamflow records used in this study do not cover a common period which is the preferred basis for comparative trend analysis. However, a reduced common record of $30 \mathrm{yr}$ from 1966 to 1995 for 12 stations was used to test the reliability of conclusions from the larger data set.

\section{Methods}

\subsection{Trend analysis}

Trend analysis of a hydrological series is of practical importance because of the effects of climate change and is generally conducted using either a parametric or a nonparametric test. Hydrometeorological time series are often characterized by data that are not normally distributed, and therefore nonparametric tests are considered more robust compared to their parametric counterparts (Hess et al., 2001). In this study, two nonparametric statistical techniques have been used for the analysis of hydrometeorological data: (1) the Mann-Kendall test in combination with trend-free prewhitening approach (Von Storch, 1995; Kulkarni and von Storch, 1995) for trend detection and distribution of the test statistic, and (2) the Sen's slope method (Sen, 1968), for the determination of long-term trend magnitude.

The Mann-Kendall test (Mann, 1945; Kendall, 1975) is one of the most widely used nonparametric tests for trend detection in hydrometeorological time series (Burn, 2008; Burn et al., 2010; Khattak et al., 2011). Mann-Kendall has the advantage of robustness against departures from normality in data. Additionally, it is less affected by outliers because its statistic is based on the sign of differences, and not directly on the value of the random variables. The statistic $S$, as given in Eq. (1), is computed through comparing each value of the time series with the remaining in a sequential order.

$S=\sum_{k=1}^{n-1} \sum_{j=k+1}^{n} \operatorname{Sgn}\left(x_{j}-x_{k}\right)$

where

$\operatorname{Sgn}\left(x_{j}-x_{k}\right)=\left[\begin{array}{rl}1 & \text { if }\left(x_{j}-x_{k}\right)>0 \\ 0 & \text { if }\left(x_{j}-x_{k}\right)=0 \\ -1 & \text { if }\left(x_{j}-x_{k}\right)<0\end{array}\right]$,

$x_{j}$ and $x_{k}$ are the sequential data values, and $n$ is the length of the data set. For samples greater than 10, the test is conducted using normal distribution (Helsel and Hirsch, 1992) with the mean $(E)$ and variance (Var) shown in Eqs. (3) and (4):

$E[S]=0$,

$\operatorname{Var}(S)=\frac{1}{18}\left[n(n-1)(2 n+5)-\sum_{p=1}^{q} t_{p}\left(t_{p}-1\right)\left(2 t_{p}+5\right)\right]$

where $t_{p}$ is the number of ties value for the $p$ th group and $q$ is the number of tied group. The standardized test statistic $\left(Z_{\mathrm{mk}}\right)$ is calculated in Eq. (5) by

$Z_{\mathrm{mk}}=\left[\begin{array}{ll}\frac{S-1}{\sqrt{\operatorname{Var}(S)}} & \text { if } S>0 \\ \frac{S+1}{\sqrt{\operatorname{Var}(S)}} & \text { if } S<0 \\ 0 & \text { if } S=0\end{array}\right]$

where the value of $Z_{\mathrm{mk}}$ is the Mann-Kendall test statistic that follows standard normal distribution with mean of zero and variance of one. In a two-sided test for trend, the null hypothesis $H_{o}$ is accepted if $-Z_{1-\alpha / 2} \leq Z_{\mathrm{mk}} \leq Z_{1-\alpha / 2}$, where $\alpha$ is the significance level that indicates the trend strength.

Trend evaluation using the Mann-Kendall test relies on two important statistical metrics - the trend significance level or the $p$ value, and the trend slope $\beta$. The $p$ value is an indicator of the trend strength, and $\beta$ provides the rate of change in the variable allowing determination of the total change during the analysis period. The presence of serial correlation in a data set can affect the outcome of the Mann-Kendall test; the version of the trend test used herein incorporates a correction, developed by Yue et al. (2002). The variance of Mann-Kendall statistic $S$ also incorporates a correction for ties when $x_{i}=x_{j}$ (Salas, 1993).

Burn and Elnur (2002), Burns et al. (2007), Burn (2008), and Zhang and $\mathrm{Lu}$ (2009), among others, have estimated the slope of an existing trend in hydrometeorological data using the Sen's slope method. The method involves computing slopes for all the pairs of ordinal time points and then using the median of these slopes as an estimate of the overall slope. The Sen's slope method is insensitive to outliers and can be effectively used to quantify a trend in the data. 
Table 2. Description of variables.

\begin{tabular}{lll}
\hline S. No & Abbreviation & Description \\
\hline Set A & & \\
1 & JFMP & January to March flow as proportion of annual flow \\
2 & AMP & April and May flow as proportion of annual flow \\
3 & JJP & June and July flow as proportion of annual flow \\
4 & ASP & August and September flow as proportion of annual flow \\
5 & ONDP & October to December flow as proportion of annual flow \\
6 & AF & Annual volume of flow \\
7 & JFM & January to March flow volume \\
8 & AM & April and May flow volume \\
9 & JJ & June and July flow volume \\
10 & AS & August and September flow volume \\
11 & OND & October to December flow volume \\
\hline Set B & & \\
12 & SOT & Timing of spring onset \\
13 & CoV & Centre of volume date \\
\hline Set C & & \\
14 & YDP & Sum of flows at Yugo and Dainyore as proportion of flow at Partab Bridge \\
15 & YDB & Sum of flows at Yugo and Dainyore as proportion of flow at Besham \\
16 & YK & Flow at Yugo as proportion of flow at Kachura \\
17 & DAB & Flow at Dainyore as proportion of Alam Bridge \\
\hline
\end{tabular}

\subsection{Timing and magnitude variables}

Trend analysis was conducted on the time series of variables listed in Table 2 using the Mann-Kendall nonparametric trend test. A total of 17 hydrological variables of streamflow magnitude and timing were investigated for trends. These have been grouped in three sets.

Set A comprises seasonal and annual flow and proportions of annual flows for each of five seasons (variables 1 to 11 in Table 2) and were applied to all 19 stations for which monthly data were available. The seasons have been defined in relation to the melt season and also to the direction of the monthly temperature trend shown in Fig. 3. Thus the spring months of April and May encompass the initiation of melt in a period when temperature trends are significantly upward, the early summer months of June and July the peak of the runoff hydrograph with downward-trending temperatures, and late summer months of August and September a period with depleted snowmelt sources and declining temperature. The winter period has been divided between October to December and January to March. Aguado et al. (1992) noted the importance of distinguishing between timing trends in actual streamflow and the proportional flow for a given period, quoting an example where seasonal precipitation and runoff have increased but the proportion of annual flow has significantly declined. However as discussed in Sect. 6, reference only to proportional flows can lead to false conclusions and interpretation needs to be combined with changes in actual seasonal flow.
Set B comprises two flow and timing measures for sixteen stations based on daily flow:

1. The date of the beginning of the spring snowmeltderived streamflow for snowmelt-dominated rivers (a measure of spring onset timing (SOT) Variable 12). This uses the procedure described by Cayan et al. (2001) wherein the day with the most negative cumulative departure from mean flow is identified. This is equivalent to finding the day after which most flows are greater than the annual average.

2. The CoV (Variable 13), which may be defined as the date by which $50 \%$ of the annual flow has passed through the gauging station using January 1 as the starting date (Regonda et al., 2005). In contrast, measures based on a daily peak as shown in Fig. 2 may be influenced by short-lived synoptic events (e.g., exceptional temperatures) rather than the seasonal climate, the $\mathrm{CoV}$ is more broadly based on seasonal climate.

In addition to examining trends, relationships between magnitude and timing variables are also investigated.

Set C comprises three variables (14 to 17$)$ which provide indices of the proportional contribution of glacial melt to total flow at three stations on the main stem of the Indus at Kachura, Partab Bridge and Besham by summing the flow from the glacial regime Shyok and Hunza in relation to the total flow. Additionally, the proportional contribution of the glacial Hunza to the Gilgit River at Alam Bridge is quantified in Variable 17. The flow from these high-elevation 
Table 3. Number of stations with (significant) positive or negative trends in (a) seasonal proportions of annual flow and (b) annual and seasonal flow.

\begin{tabular}{|c|c|c|c|c|c|c|}
\hline & Annual & JFM & $\mathrm{AM}$ & $\mathrm{JJ}$ & AS & OND \\
\hline \multicolumn{7}{|c|}{ A. Seasonal proportions of annual flow } \\
\hline No. + & & 12 & 10 & 5 & 9 & 12 \\
\hline No. - & & 7 & 9 & 11 & 10 & 7 \\
\hline No. Sig + & & 2 & 3 & 0 & 0 & 6 \\
\hline No. Sig - & & 0 & 0 & 5 & 0 & 1 \\
\hline \multicolumn{7}{|c|}{ B. Seasonal and annual flow } \\
\hline No. + & 13 & 15 & 12 & 12 & 14 & 16 \\
\hline No. - & 6 & 4 & 7 & 7 & 5 & 3 \\
\hline No. Sig + & 4 & 5 & 4 & 4 & 3 & 6 \\
\hline No. Sig - & 1 & 0 & 0 & 2 & 1 & 0 \\
\hline
\end{tabular}

$\mathrm{Sig}=$ Trends significant at the $5 \%$ level.

catchments is predominantly of glacial origin and, as shown in Fig. 2, they have a later peak flow (and centre of volume) than remaining catchments which are predominantly snow fed. It is hypothesized that a decreasing/increasing trend in the relative proportion of the glacial flow would lead to earlier/later runoff (decreasing CoV). The trend in these four variables of glacial proportion is investigated first, followed by the relationship between glacial proportion and the centre of timing.

\section{Results}

Trend analysis was carried out on the 17 variables using the Mann-Kendall nonparametric test. For the first set of variables, a summary of the direction and significance of trends is shown in Table 3. The spatial distribution of these trends is shown in Fig. 5. For the second set of variables the trend slope $\beta$ and the $p$ value are shown in Table 4, and for the third set of variables in Table 5 .

\subsection{Trend in seasonal proportions}

Following the example of analysis in western North America by Aguado et al. (1992), analysis first considers trends in seasonal proportion. However, unlike the western United States, none of the trends in seasonal proportion of flow (Table 3a) provide a consistent pattern of change, either for the full station set or for groups of catchments within a single regime.

For the spring period of April and May there are three catchments with significantly positive trends and none significantly negative. The southward-flowing tributaries, Jhelum and Swat, have positive trends, in some cases significant, whereas the higher nival regime catchments show predominantly negative but insignificant trends. In contrast, the early summer period of June and July has predominantly negative
Table 4. Trends in flow magnitude and timing measures based on daily data.

\begin{tabular}{|c|c|c|c|c|}
\hline \multirow[b]{2}{*}{ Station } & \multicolumn{2}{|c|}{ SOT } & \multicolumn{2}{|c|}{$\mathrm{CoV}$} \\
\hline & Beta & $p$ & Beta & $P$ \\
\hline Yugo & +0.071 & 0.658 & 0 & 0.74 \\
\hline Dainyore & +0.056 & 0.664 & 0 & 0.888 \\
\hline Kharmong & -0.400 & 0.99 & +0.833 & 0.252 \\
\hline Gilgit & +0.167 & 0.598 & -0.222 & 0.526 \\
\hline Doyien & 0 & 1 & 0 & 0.894 \\
\hline Chitral & 0 & 0.84 & +0.154 & 0.086 \\
\hline Kalam & 0 & 0.886 & -0.036 & 0.486 \\
\hline Naran & +0.091 & 0.586 & +0.029 & 0.726 \\
\hline Kachura & 0 & 0.914 & 0 & 0.958 \\
\hline Alam & 0 & 0.87 & 0 & 0.77 \\
\hline Partab & -0.188 & 0.138 & -0.125 & 0.082 \\
\hline Besham & +0.129 & 0.474 & 0 & 0.79 \\
\hline Chakdara & -0.208 & 0.214 & -0.091 & 0.27 \\
\hline Karora & -0.143 & 0.91 & +0.143 & 0.8 \\
\hline G.Habibul & -0.130 & 0.36 & -0.076 & 0.332 \\
\hline Muzaff. & -0.522 & $(0.004)$ & -0.333 & 0.053 \\
\hline No. + & 5 & & 4 & \\
\hline No. - & 6 & & 6 & \\
\hline No. Sig + & 0 & & 0 & \\
\hline No. Sig - & 1 & & 0 & \\
\hline
\end{tabular}

Note: Positive trends are shown in dark grey; negative trends in light grey. Trends significant at the $5 \%$ level are shown in bold and bracketed. $p$ is the probability that the null hypothesis $H_{0}$ of no trend could be rejected.

trends which are significant at five stations mainly in the southward-flowing Jhelum and Swat catchments. However, again, neighbouring stations often show trends with different signs. Late summer (August and September) has a nearly equal number of negative and positive trends, none of them being significant. The winter periods from October to December and January to March have the most consistent trends, with 12 of 14 stations in the glacial and nival catchments showing positive trends in early winter with six of these significant. Late winter trends are also predominantly positive but with fewer significant ones than for the early winter and less consistency in their location.

Discussion in Sect. 6 shows why proportional seasonal flow provides an unreliable indication of actual change.

\subsection{Trend in seasonal volumes}

The spatial distribution of annual and seasonal volume trends is shown in Fig. 5 and summarized in Table 3b. Considering actual flow rather than proportional flow yields more consistent results. Annual flows have significantly increased at four stations, mainly in the seasonal snowmelt regime. Six stations including the Astore at Doyien (Fig. 6b and d) have increasing trends in all seasons. In contrast the glacial-regime station, the Hunza at Dainyore, has decreasing trends in all seasons and annually (Fig. 6a and c). For the early melt season (April/May), four stations have significantly increased 


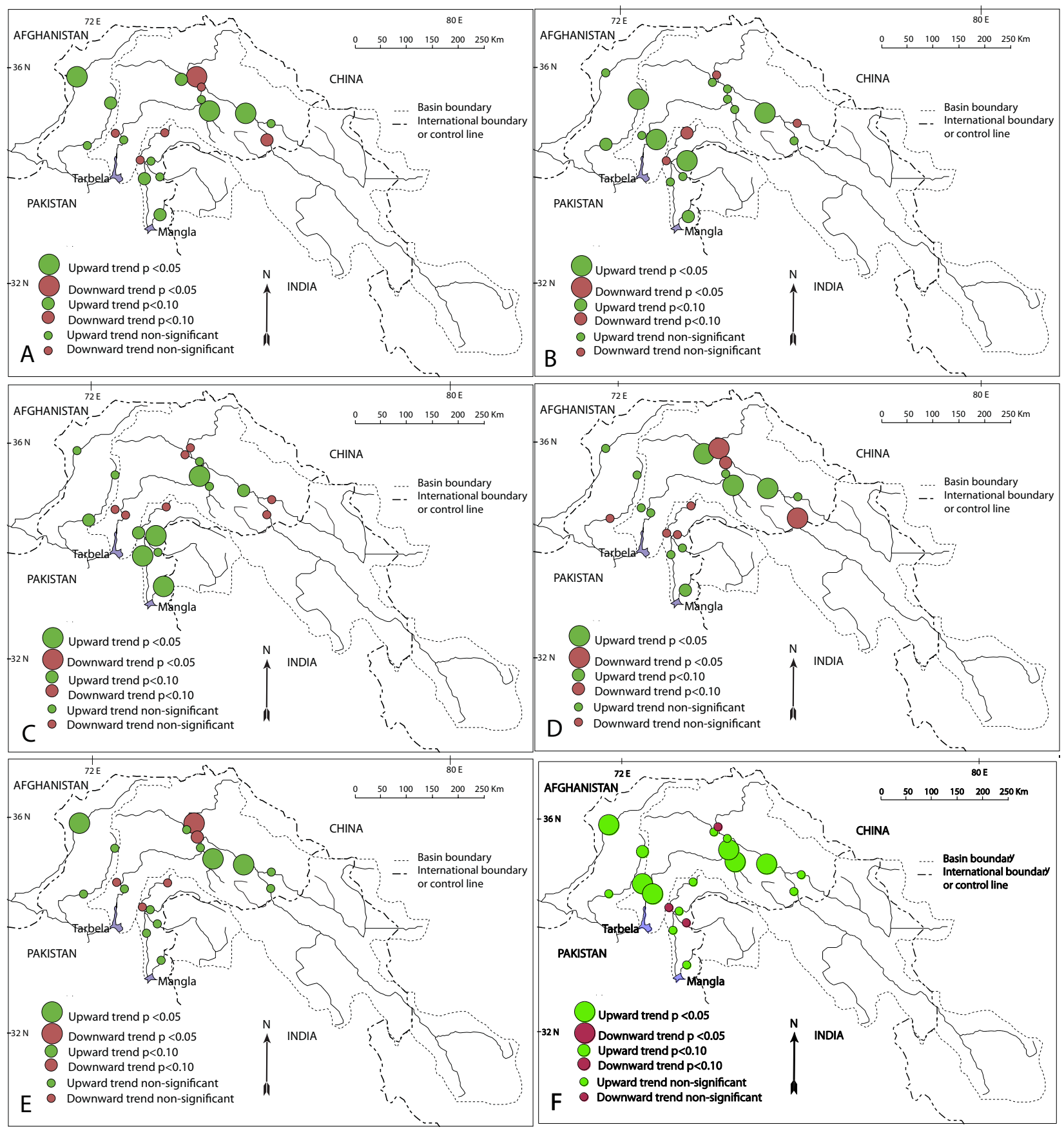

Fig. 5. Spatial distribution of trends in annual and seasonal flow magnitude. (A) annual trend, (B) January-March trend, (C) April-May trend, (D) June-July trend, (E) August-September trend, (F) October-December trend.

flow, either on the main stem of the Indus (Kachura and Partab Bridge) with mixed glacial and nival regimes or on the southward-flowing tributaries of Jhelum and Swat, affected in this spring season by both snowmelt and direct runoff from rainfall (but before the monsoon). Although no stations have significantly negative trends in this spring period, the high-level stations of Dainyore and Kharmong have significantly negative trends in the following June/July period.
Elsewhere predominantly positive trends continue through the summer months. Furthermore, during the winter the positive trend continues with all but 4 of 19 stations showing positive trends, with six significant at the $5 \%$ level.

A similar proportion and location of positive and negative trends was found for the reduced common data sets from 1966 to 1995 although the proportion of stations with significant trends decreased. 

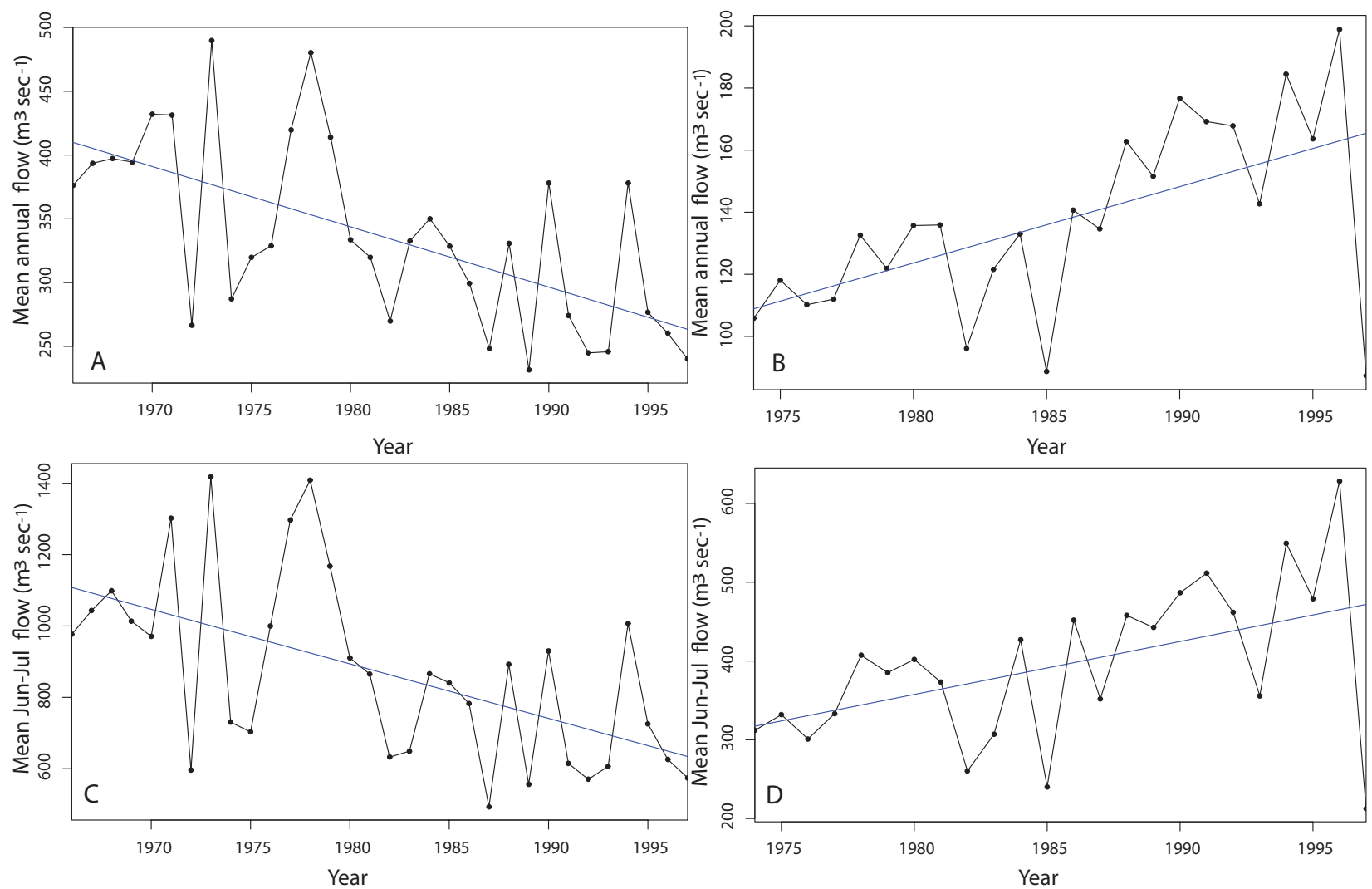

Fig. 6. Trends in seasonal and annual flow. (A) annual trend for the Hunza at Dainyore, (B) annual trend for the Astore at Doyien, (C) June-July trend at Dainyore and (D) June-July trend at Doyien.

\subsection{Trend in daily timing and magnitude variables}

With respect to timing, positive values indicate trends towards a later date of occurrence and negative values indicate earlier occurrence. However, significant trends based on daily flow are even fewer than those based on monthly data and there is little consistency in the direction of trend (Table 4).

The SOT exhibits an equal number of increasing and decreasing trends and only one is significant. Similarly the $\mathrm{CoV}$ timing has a near-equal share of positive and negative trends, and none is significant at the $5 \%$ level.

\subsection{Relationships of magnitude and timing}

As noted in Sect. 1, Déry et al. (2009) found that CoV may be influenced by runoff magnitude. Alford (2011) showed that for the Indus at Besham, seasonal flood peaks tended to occur earlier in high-flow years. Regression analysis between the annual volume of flow (AV) and CoV (Table 5) does indeed show that there is a predominantly negative relationship; larger volume gives an earlier centre of timing. The relationship is strongest for glacial and high-elevation catchments and weak or positive for some southern tributaries. On the other hand there is no consistent or significant relationship between annual flow volume and SOT. However, spring onset timing and centre of volume are positively correlated at all stations with eleven significant at the $5 \%$ level.

\subsection{Relationship between flow regime and timing trends}

Table 6 shows trends in the proportion of flow from glacialregime catchments to total flow in the main stem of the Indus. On all four catchments there is a decreasing trend (three significant) in the contribution from the glacial catchments. The beta (slope) value indicates the magnitude of the change; a slope value of -0.005 for Partab Bridge represents a $17.5 \%$ decline in the contribution from Hunza and Shyok to the main river over its $35 \mathrm{yr}$ of record.

However, the analysis (Table 7) does not support the hypothesis stated in Sect. 4.2 that decreasing trend in the glacial proportion should lead to earlier $\mathrm{CoV}$ on the main stem of the Indus. In three of the four catchments the response is in the opposite direction, but in no case is the relationship significant. 
Table 5. Correlation coefficient relationships between timing and magnitude variables.

\begin{tabular}{|c|c|c|c|c|c|c|}
\hline Station & $\begin{array}{l}\text { AV: } \\
\text { SOT }\end{array}$ & $P$ & $\begin{array}{l}\text { AV: } \\
\text { CoV }\end{array}$ & $p$ & $\begin{array}{l}\text { SOT: } \\
\text { CoV }\end{array}$ & $p$ \\
\hline Yugo & +0.06 & 0.77 & -0.43 & $(0.03)$ & +0.29 & 0.16 \\
\hline Dainyore & -0.10 & 0.57 & -0.44 & 0.10 & +0.27 & 0.12 \\
\hline Kharmong & +0.22 & 0.56 & -0.49 & 0.18 & +0.53 & 0.13 \\
\hline Gilgit & -0.10 & 0.68 & -0.28 & 0.25 & +0.49 & $(0.03)$ \\
\hline Doyien & +0.13 & 0.53 & -0.02 & 0.93 & +0.48 & (0.01) \\
\hline Chitral & -0.33 & 0.05 & -0.29 & 0.10 & +0.30 & 0.09 \\
\hline Kalam & +0.30 & 0.07 & +0.10 & 0.55 & +0.53 & $(<\mathbf{0 . 0 0 1})$ \\
\hline Naran & +0.20 & 0.15 & +0.14 & 0.29 & +0.61 & $(<\mathbf{0 . 0 0 1})$ \\
\hline Kachura & -0.40 & $(0.02)$ & -0.36 & $(0.05)$ & +0.43 & (0.01) \\
\hline Alam Br. & +0.13 & 0.45 & -0.03 & 0.88 & +0.37 & $(0.03)$ \\
\hline Partab & -0.26 & 0.13 & -0.35 & $(0.04)$ & +0.52 & $(<\mathbf{0 . 0 0 1})$ \\
\hline Besham & -0.26 & 0.17 & -0.41 & $(0.03)$ & +0.27 & 0.157 \\
\hline Chakdara & -0.14 & 0.42 & -0.33 & $(0.04)$ & +0.59 & $(<\mathbf{0 . 0 0 1})$ \\
\hline Karora & +0.11 & 0.62 & -0.21 & 0.35 & +0.53 & (0.01) \\
\hline Garhi Habib. & +0.22 & 0.23 & +0.24 & 0.20 & +0.53 & $(<\mathbf{0 . 0 0 1})$ \\
\hline Muzafferabad & +0.42 & $(0.02)$ & +0.51 & $(0.004)$ & +0.55 & $(<0.001)$ \\
\hline No. + & 9 & & 4 & & 16 & \\
\hline No. - & 7 & & 12 & & 0 & \\
\hline No. Sig + & 1 & & 1 & & 11 & \\
\hline No. Sig - & 1 & & 5 & & 0 & \\
\hline
\end{tabular}

Note: Positive trends are shown in dark grey; negative trends in light grey. Trends significant at the $5 \%$ level are shown in bold and bracketed. $p$ is the significance level associated with the correlation coefficient.

\section{Discussion}

The analysis provides evidence of some changes in UIB flow magnitude and timing over the period of analysis from the mid 1960 s to the late 1990 s. With respect to seasonal proportions, which describe changing flow seasonality, potentially the most important observed trend in the UIB is the reduction in the proportion of flow occurring in early summer (June and July) (Table 3a), which represents the months at many stations when the greatest volume of runoff occurs, and accompanying increasing trends in winter. This could occur due to a transfer of runoff from the summer to the winter season (i.e., winter flow getting bigger as summer flow gets smaller). However, as the seasonal proportions describe only the flow seasonality and nothing about the actual volume of flow, changes to flow volume itself could be quite different. Examination of the actual flow volumes (Fig. 5, Table 3b) shows that there are a number of contrasting examples: two are examined in detail here, for the Hunza at Dainyore and the Astore at Doyien.

At Dainyore, JJ and AS have a downward trend for proportion (though not significant) whilst JFM, AM and OND have upward trends, all significant. However, for actual flow, the trend is downward in all seasons (and all months except May and December) (Figs. 5, 6a and c). The summer months with a much larger flow and larger actual reductions are compensated by significant increases in proportional winter flow even though actual winter flow also has a decreasing trend.

At Doyien, AM and JJ have a downward trend of proportion (though again not significant) whilst JFM, AS and
OND have upward trends, the last being significant. Looking at seasonal and monthly trends in actual flow (Fig. 6b and d), every single month of winter and summer has an upward trend, but the most significant changes $(p<0.01)$ are in the winter months.

There is therefore a danger of serious misinterpretation in using proportional flow alone. Given the actual low flows during the winter months, the contrast between early summer and winter proportional trends does not represent a simple transfer from summer to winter, nor does it represent a greater proportion of winter precipitation falling as rain rather than snow as in lower catchments in western North America (Regonda et al., 2005). The greater part of noted catchments is above the freezing level throughout the winter, and the valley floors below the freezing level have little precipitation of any kind.

What then can be concluded from Fig. 5 in the relationship between changes in climate and actual streamflow? Annual flow has predominantly increased - 4 stations significantly positive and only 1 high-level station (Dainyore) significantly negative. Seasonally, the positive trends are predominantly in winter (OND, JFM) and spring (AM). As shown in Fig. 3, upward temperature trends occur over this period, contrasting with stable or downward trends in summer, suggesting a broad response of winter flow to temperature trends. Summer streamflow trends are predominantly positive, responding to mixed drivers of increased winter precipitation for catchments where the main source is seasonal snowmelt and increased summer precipitation for lower-elevation tributaries. Only the high-level stations show significant negative trends.

Using daily flow records, trends in neither SOT nor CoV (Table 4) support a general change in timing of the annual hydrograph with equal values of earlier (negative) and later (positive) trends in both, and only one statistically significant at the $5 \%$ level. This result is in marked contrast to streamflow trends in western North America where widespread and significant changes to earlier timing occurred in both SOT (Cayan et al., 2001) and CoV (Regonda et al., 2005).

However, there is a consistent relationship between $\mathrm{CoV}$ and the AV (Table 5) with 12 of 16 stations showing an earlier (negative) $\mathrm{CoV}$ for a higher runoff value, with 5 significant $(p<0.05)$. This is quite the opposite of the simulation results of Déry et al. (2009) who found that, for a hypothetical catchment dominated by melt of seasonal snow, reducing the volume alone advances CoV simply by reducing the amount of snow available for melt later in the season. A possible explanation for this contrasting relationship in the UIB is that in years of high snowfall and runoff volume a greater proportion of the snow falls at lower elevations and therefore melts earlier as spring temperatures rise. The high-level glacier-fed catchments (Dainyore and Yugo) where runoff is not limited by seasonal storage also show a strong negative relationship between volume and timing, possibly indicating a higher proportion of seasonal snowmelt compared with glacial runoff in years with higher volume. The impact of trend in runoff 
Table 6. Trend in the comparative annual contribution of glacial-regime catchments to combined flow.

\begin{tabular}{|c|c|c|c|c|c|c|c|}
\hline \multicolumn{2}{|c|}{ YDP } & \multicolumn{2}{|c|}{ YDB } & \multicolumn{2}{|c|}{ YK } & \multicolumn{2}{|c|}{ DAB } \\
\hline Slope & $p$ & Slope & $p$ & Slope & $p$ & Slope & $p$ \\
\hline-0.005 & $(0.030)$ & -0.003 & (0.017) & -0.003 & 0.073 & -0.003 & $(0.015)$ \\
\hline
\end{tabular}

Table 7. Relationship between glacial proportion of Indus main stem flow and centre of volume.

\begin{tabular}{|c|c|c|c|c|c|c|c|}
\hline \multicolumn{2}{|c|}{ YDP } & \multicolumn{2}{|c|}{ YDB } & \multicolumn{2}{|c|}{ YK } & \multicolumn{2}{|c|}{ DAB } \\
\hline$r$ & $p$ & $r$ & $p$ & $r$ & $p$ & $r$ & $p$ \\
\hline-0.15 & 0.49 & -0.18 & 0.39 & 0.02 & 0.92 & -0.20 & 0.35 \\
\hline
\end{tabular}

volume is less evident in its relationship with SOT with just two significant trends, one positive and one negative.

One relationship which is consistent for all stations is the positive correlation between SOT and CoV (Table 5). This relationship implies that once the timing pattern of runoff is established early in the season it continues throughout the season and that a pre-existing condition (presumably winter precipitation) at the onset of the season influences the timing throughout. This conclusion is supported by Archer (2003) for the Indus and Archer and Fowler (2008) for the Jhelum; both of whom showed that summer runoff volume is significantly linked with winter (October to March) precipitation, whilst Archer and Fowler (2004) found statistically significant $(p<0.05)$ upward trends in winter precipitation across the region.

Runoff timing and magnitude trends are consistent with reported changes both in glacial behavior in the Karakoram and with trends in climate. On high-level catchments (notably the Hunza and Shyok), where seasonal summer runoff is primarily derived from melt of glaciers and perennial snow, concurrent summer temperature controls the volume of summer runoff (Fowler and Archer, 2006). Declining trends in summer temperature (Fig. 3) are accompanied by a falling trend in runoff notably on the Hunza catchment (Table 3, Figs. 5 and 6) and a declining proportion of glacial contribution to the main stem of the Indus (Table 6). Whilst changes in precipitation also influence glacier mass balance, a falling trend in summer energy input is expected to change glacier mass balance in favour of increased storage and reduced runoff. Indeed, thickening and advance of many Karakoram glaciers has been reported in recent decades (Hewitt, 2005, 2007, 2011). Analysis of ice loss using satellite gravimetry from 2003 to 2009 (Matsuo and Heki, 2010) seems to confirm that glacier loss is reduced in the Karakoram compared with the neighbouring Himalaya. Trans-Himalayan glacier behavior is quite different from the eastern and central Himalaya where significant retreat and depletion of glacier volume has occurred (Eriksson et al., 2009; Berthier et al., 2007).
For nival catchments the predominant influence on streamflow volume is the magnitude of winter precipitation (Archer, 2003; Archer and Fowler, 2008). Since both winter and summer precipitation are increasing, at least for stations at low elevation (Archer and Fowler, 2004), streamflow volume also has a predominantly increasing trend. This study suggests that the magnitude of winter precipitation also strongly influences timing of the runoff hydrograph with higher annual flow volume being linked with earlier centre of volume.

For those catchments on the southern margin, periodic and variable contribution from monsoon rainfall to streamflow add to the variability and magnitude of streamflow without a consistent trend.

\section{Conclusions}

Flow is a synthesis at a point of the energy and moisture inputs to a catchment and to the impact of seasonal and long-term storages of water in soil, snow and glaciers. Trends in flow thus provide composite indicators of the impact of changing climate in catchments where measurement of climatic variables at elevations above $4000 \mathrm{~m}$, where most runoff is generated, is impractical or very difficult. This analysis provides a basis for decoupling the component changes (or lack of them) in streamflow magnitude and timing for glacial and nival catchments.

High-level glacial catchments, notably the Hunza, show a falling trend in runoff (Table 3, Figs. 5 and 6) and a declining proportion of glacial contribution to the main stem of the Indus (Table 6). The downward trend is attributed primarily to a falling trend in summer temperatures. This observation is in contrast to projections based on global climate change (Rees and Collins, 2006; Briscoe and Qamar, 2007), which suggest temporary and short-term increases in river flow followed by a sharp decrease in river flows as glacial area diminishes. Karakoram climate and runoff is clearly out of step with global change.

Nival catchments dependent on melt of winter snow show a predominant upward trend in runoff volume (Fig. 5) which 
is linked to the upward trend in winter precipitation (Archer and Fowler, 2004). However the changes are neither as consistent nor as marked as observed, for example, in western North America (Aguado et al., 1992).

Furthermore, there is no evidence of a consistent trend in runoff timing either in onset of spring runoff or of the centre of volume of the annual hydrograph (Table 4). This result is again in contrast to observations of significant timing shifts in western North America over a similar time period (Cayan et al., 2001; Regonda et al., 2005) and elsewhere (Dettinger and Diaz, 2000).

Variability in the centre of volume is linked to annual runoff volume (Table 5) - and presumably to the initial volume of winter snowpack. The link between runoff timing and initial snowpack is further supported by the consistent and significant correlation between spring onset and centre of volume timing (Table 5). Initial conditions before the onset of runoff influence timing throughout the season.

Whilst trends in flow magnitude and timing are potentially of practical importance for river basin management and particularly for the operation of the control reservoirs at Tarbela and Mangla, trends at stations upstream from Tarbela (Besham) and Mangla (Kohala) are still small in comparison to variability. It is concluded that if reservoir operating systems are flexibly designed to respond to the variability of experienced droughts and floods, such as have occurred in the past decade, then they are likely to be able to cope with changes expected in the short to medium term as the result of climate change.

It is recommended that trend analysis be brought up to date for the upper Indus as soon as flow records are made available. In addition, conditions and impacts of trends in flow and links with climate and glacier mass balance may differ significantly in the Central Himalaya, dominated by summer monsoon rather than winter precipitation. Comparative evaluation of runoff trends there is strongly recommended.

Acknowledgements. The authors thank the Pakistan Meteorological Department and the Water and Power Development Authority for the provision of climate and flow data.

Edited by: J. Freer

\section{References}

Aguado, E., Cayan, D. R., Riddle, L., and Roos, M.: Climatic fluctuations and the timing of West Coast streamflow, J. Climate, 5, 1468-1481, 1992.

Ahmad, S., Hussain, Z., Qureshi, A. S., Majeed, R., and Saleem, M.: Drought mitigation in Pakistan: Current status and options for future strategies , International Water Management Institute, Working Paper 85, Drought Series, Paper 3, 56 pp., 2004.

Alford, D.: Hydrology and Glaciers in the Upper Indus Basin, World Bank Technical Report. South Asia Sustainable Develop- ment (SASDN), South Asia Agriculture and Rural Development Unit, The World Bank, Washington, DC, 2011.

Archer, D. R.: Contrasting hydrological regimes in the upper Indus Basin, J. Hydrol., 274, 198-210, doi:10.1016/S00221694(02)00414-6, 2003.

Archer, D. R.: Hydrological implications of spatial and altitudinal variation in temperature in the upper Indus basin, Nord. Hydrol., 35, 213-227, 2004.

Archer, D. R. and Fowler, H. J.: Spatial and temporal variations in precipitation in the Upper Indus Basin, global teleconnections and hydrological implications, Hydrol. Earth Syst. Sci., 8, 47-61, doi:10.5194/hess-8-47-2004, 2004.

Archer, D. R. and Fowler, H. J.: Using meteorological data to forecast seasonal runoff on the River Jhelum, Pakistan, J. Hydrol., 361, 10-23, doi:10.1016/j.jhydrol.2008.11.004, 2008.

Archer, D. R., Forsythe, N., Fowler, H. J., and Shah, S. M.: Sustainability of water resources management in the Indus Basin under changing climatic and socio economic conditions, Hydrol. Earth Syst. Sci., 14, 1669-1680, doi:10.5194/hess-14-16692010, 2010.

Barnett, T. P., Pierce, D. W., Hidalgo, H. G., Bonfils, C., Santer, B. D., Das, T., Bala, G., Wood, A. W., Nozawa, T., Mirin, A. A., Cayan, D. R., and Dettinger, M. D.: Human-Induced Changes in the Hydrology of the Western United States, Science, 319, 1080, doi:10.1126/science.1152538, 2008.

Berthier, E., Arnaud, Y., Kumar, R., Ahmad, S., Wagnon, P., and Chevallier, P.: Remote sensing estimates of glacier mass balances in the Himachal Pradesh (Western Himalaya, India), Remote Sens. Environ., 108, 327-338, doi:10.1016/j.rse.2006.11.017, 2007.

Bookhagen, B. and Burbank, D. W.: Towards a complete Himalayan hydrologic budget: the spatiotemporal distribution of snow melt and rainfall and their impact on river discharge, J. Geophys. Res., 115, F03019, doi:10.1029/2009JF001426, 2010.

Briscoe, J. and Qamar, U.: Pakistan's Water economy running dry, Oxford University Press, Karachi, Commissioned by World Bank, 2007.

Burn, D. H.: Hydrologic effects of climatic change in westcentral Canada, J. Hydrol., 160, 53-70, doi:10.1016/00221694(94)90033-7, 1994.

Burn, D. H.: Climatic influences on streamflow timing in the headwaters of the Mackenzie River Basin, J. Hydrol., 352, 225-238, doi:10.1016/j.jhydrol.2008.01.019, 2008.

Burn, D. H. and Elnur, M. A. H.: Detection of hydrologic trend and variability, J. Hydrol., 255, 107-122, 2002.

Burn, D. H., Sharif, M., and Zhang, K.: Detection of trends in hydrological extremes for Canadian watersheds, Hydrol. Process., 24, 1781-1790, doi:10.1002/hyp.7625, 2010.

Burns, D. A., Klaus, J., and McHale, M. R.: Recent climate trends and implications for water resources in the Catskill Mountain region, New York, USA, J. Hydrol, 336, 155-170, doi:10.1016/j.jhydrol.2006.12.019, 2007.

Cayan, D. R., Kammerdiener, S. A., Dettinger, M. D., Caprio, J. M., and Peterson, D. H.: Changes in the onset of spring in the western United States, B. Am. Meteorol. Soc., 82, 399-415, 2001.

Cramer, T.: Climatological investigation in Bagrot Valley, In: Cultural Area Karakoram Newsletter, 3, 19-22, Tubingen, 1993.

Cruz, R. V., Harasawa, H., Lal, M., Wu, S., Anokhin, Y., Punsalmaa, B., Honda, Y., Jafari, M., Li, C., and Huu Ninh, N.: Asia. Cli- 
mate Change 2007: Impacts, Adaptation and Vulnerability. Contribution of Working Group II to the Fourth Assessment Report of the Intergovernmental Panel on Climate Change, edited by: Parry, M. L., Canziani, O. F., Palutikof, J. P., van der Linden, P. J., and Hanson, C. E., Cambridge University Press, Cambridge, UK, 469-506, 2007.

Déry, S. J., Stahl, K., Moore, R. D., Whitfield, P. H., Menounos, B., and Burford, J. E.: Detection of runoff timing changes in pluvial, nival, and glacial rivers of western Canada. Water Resour. Res., 45, W04426, doi:10.1029/2008WR006975, 2009.

Dettinger, M. D. and Diaz, H. F.: Global characteristics of stream flow seasonality and variability, J. Hydrometeorol., 1, 289-310, 2000.

Eriksson, M., Xu, J., Shrestha, A. B., Vaidya, R. A., Nepal, S., and Sandström, K.: The changing Himalayas: Impact of climate change on water resources and livelihoods in the greater Himalayas, ICIMOD, Kathmandu, 2009.

Forsythe, N., Kilsby, C. G., Fowler, H. J., and Archer, D. R.: Assessing climate pressures on glacier-melt and snowmelt-derived runoff in the Hindu Kush-Karakoram sector of the Upper Indus Basin, in Role of Hydrology in Managing Consequences of a Changing Global Environment, Proceedings of 3rd BHS International Symposium, Newcastle upon Tyne, July 2010, 2010.

Fowler, H. J. and Archer, D. R.: Conflicting signals of climate change in the Upper Indus Basin, J. Climate, 19, 4276-4292, 2006.

Helsel, D. R. and Hirsch, R. M.: Statistical methods in water resources, Elsevier, New York, 1992.

Hess, A., Lyer, H., and Malm, W.: Linear trend analysis: a comparison of methods. Atmos. Environ., 35, 5211-5222, doi:10.1016/S1352-2310(01)00342-9, 2001.

Hewitt, K.: The Karakoram Anomaly? Glacier Expansion and the "Elevation Effect", Karakoram Himalaya, Mt. Res. Dev., 25, 332-340, 2005.

Hewitt, K.: Tributary glacial surges: an exceptional concentration at Panmah Glacier, Karakoram Himalaya, J. Glaciol., 53, 181-188, 2007.

Hewitt, K.: Glacier change, concentration, and elevation effects in the Karakoram Himalaya, Upper Indus Basin, Mt. Res. Dev., 31, 188-200, doi:10.1659/MRD-JOURNAL-D-11-00020.1, 2011.

Hidalgo, H. G., Das, T., Dettinger, M. D., Cayan, D. R., Pierce, D. W., Barnett, T. P., Bala, G., Mirin, A., Wood, A. W., Bonfils, C., Santer, B. D., and Nozawa, T.: Detection and attribution of streamflow timing changes to climate change in the Western United States, J. Climate, 22, 3838-3855, doi:10.1175/2009JCLI2470.1, 2009.

Houze, R. A., Rasmussen, K. L., Medina, S., Brodzik, S. R., and Romatschke, U.: Anomalous Atmospheric Events Leading to the Summer 2010 Floods in Pakistan, B. Am. Meteorol. Soc., 92, 291-298, 2011.

Immerzeel, W. W., Droogers, P., de Jong, S. M., and Bierkens, M. P. F.: Large-scale monitoring of snow cover and runoff simulation in Himalayan river basins using remote sensing, Remote Sens. Environ., 113, 40-49, doi:10.1016/j.rse.2008.08.010, 2008.

IPCC: Climate Change 2007: Impacts, Adaptation and Vulnerability, Contribution of Working Group II to the Fourth Assessment Report of the Intergovernmental Panel on Climate Change, edited by: Parry, M. L., Canziani, O. F., Palutikof, J. P., van der Linden, P. J., and Hanson, C. E., Cambridge University Press, Cambridge,
UK, 976 pp., 2007.

Kendall, M. G.: Rank Correlation Measures, Charles Griffin, London, UK, 1975.

Khattak, M. S., Babel, M. S., and Sharif, M.: Hydrometeorological trends in the upper Indus River Basin in Pakistan, Clim. Res., 46, 103-119, doi:10.3354/cr00957, 2011.

Kulkarni, A. and von Storch, H.: Monte Carlo experiments on the effect of serial correlation on the Mann-Kendall test of trend, Meteorol. Z., 4, 82-85, 1995.

Mann, H. B.: Non-parametric tests against trend, Econometrica, 13, 245-259, 1945.

Matsuo, K. and Heki, K.: Time-variable ice loss in Asian high mountains from satellite gravimetry, Earth Planet. Sc. Lett., 290 30-36, doi:10.1016/j.epsl.2009.11.053, 2010.

Rees, H. G. and Collins, D. N.: Regional differences in response of flow in glacier-fed Himalayan rivers to climatic warming, Hydrol. Process., 20, 2157-2169, doi:10.1002/hyp.6209, 2006.

Regonda, S. K., Rajagopalan, B., Clark, M., and Pitlick, J.: Seasonal cycle shifts in hydroclimatology over the western United States, J. Climate, 18, 372-384, 2005.

Roos, M.: Possible Changes in California Snowmelt Patterns, 4th Pacific Climate Workshop, Pacific Grove, California, 22-31, 1987.

Salas, J. D.: Analysis and modelling hydrologic time series, in: Handbook of Hydrology, edited by: Maidment, D. R., 19.119.72, McGraw Hill, New York, 1993.

Sen, P. K.: Estimates of the regression coefficient based on Kendall's tau, J. Am. Stat. Assoc., 63, 1379-1389, 1968.

Sheikh, M. M., Manzoor, N., Adnan, M., Ashraf, J., and Khan, A. M.: Climate Profile and Past Climate Changes in Pakistan, GCISC-RR-01, Global Change Impact Studies Centre (GCISC), Islamabad, Pakistan, ISBN: 978-969-9395-04-8, 2009.

Stahl, K., Moore, R. D., Floyer, J. A., Asplin, M. G., and McKendry, I. G.: Comparison of approaches for spatial interpolation of daily air temperature in a large region with complex topography and highly variable station density, Agr. Forest Meteorol., 139, 224 236, 2006.

Yue, S., Pilon, P. J., Phinney, B., and Cavadias, G.: The influence of autocorrelation on the ability to detect trend in hydrological series, Hydrol. Process., 16, 1807-1829, 2002.

Von Storch, H.: Misuses of statistical analysis in climate research. In Analysis of Climate Variability: Applications of Statistical Techniques, edited by: von Storch, H. and Navarra, A., SpringerVerlag: Berlin, 11-26, 1995.

Wake, C. P.: Glaciochemical investigations as a tool to determine the spatial variation of snow accumulation in the Central Karakoram, Northern Pakistan, Ann. Glaciol., 13, 279-284, 1989.

Westmacott, J. R. and Burn, D. H.: Climate change effects on the hydrological regime within the Churchill-Nelson River Basin, J. Hydrol., 202, 263-279, doi:10.1016/S0022-1694(97)00073-5, 1997.

WWF: An Overview of Glaciers, Glacier Retreat, and Subsequent Impacts in Nepal, India and China. World Wildlife Fund, Nepal Program, March, 70 pp., 2005.

Zhang, S. and Lu, X. X.: Hydrological responses to precipitation variation and diverse human activities in a mountainous tributary of the lower Xijiang, China, Catena, 77, 130-142, doi:10.1016/j.catena.2008.09.001, 2009. 